\title{
Review on Backyard Poultry Farming: Resource Utilization for Better Livelihood of the Rural Population
}

\author{
Shashi Pal ${ }^{1}$, Bhanu Prakash ${ }^{2 *}$, Anil Kumar ${ }^{2}$ and Yashwant Singh ${ }^{1}$ \\ ${ }^{1}$ KrishiVigyan Kendra, SAS Nagar, Mohali, Guru AngadDev Veterinary and Animal Sciences \\ University, Ludhiana, Punjab, India \\ ${ }^{2}$ KrishiVigyan Kendra, Tarn Taran, Guru Angad Dev Veterinary and Animal Sciences \\ University, Ludhiana, Punjab \\ *Corresponding author
}

\section{A B S T R A C T}

\section{Keywords}

Backyard poultry, Native poultry breeds, Meat, Egg and vermicompost

\section{Article Info}

Accepted:

18 April 2020

Available Online:

10 May 2020
Backyard poultry production system is the most popular poultry farming practice in rural part of India. Backyard poultry production contributes about 15 percent of total poultry output today in India. In the village, backyard poultry production is mostly based on traditional local breeds, producing both chicken meat and eggs. The laying potential of indigenous birds in terms of egg production is quite poor which ranges from 80 to 100 eggs/ bird/ year and their body weight gain is also very low. A simple backyard production requires an enclosed area which is having a few hens and a cock. Birds feed by scavenging or are provided with household scraps and crop by-products. In the recent past, improved backyard varieties (like Vanaraja, Gramapriya, Srinidhi, Giriraja, IBL80, Chabro, etc.) developed mostly by public sector and a few by private sector (like Kuroiler, Rainbow rooster) are substantially contributing to the total egg and chicken meat production in rural areas of the country. Backyard poultry manure can be used directly as fertilizer and preparation of vermicompost that can further used as fertilizer in kitchen gardening. Vermicompost can also be sold for income generation. Backyard poultry production can make a useful contribution to achieve nutritional security among rural masses and subsidiary source of income for poor households or weaker section of society.

\section{Introduction}

Backyard poultry production is an age old practice carried out by poor farmers and tribal in rural India. Most of the backyard poultry production comprises rearing of indigenous birds with poor production performances. About $66 \%$ of the total population of country still lives in rural part, which predominantly constituted by peoples, belongs to poor socioeconomic status of society i.e. poor, marginal farmers and landless labourers. Backyard poultry production system is the most popular poultry farming practice in rural poor families of society from an old era to till today. A simple backyard production system is involving a few hens (5-10 birds) and a cockerel in a simple housing system. 
Birds feed by scavenging or are provided with household kitchen waste and crop byproducts. It can be used as a powerful tool for alleviation of rural poverty, eradication of malnutrition among rural population of country. Backyard poultry is a handy enterprise with low-cost initial investment and generates employment among the poor people particularly women.

As per Watt Executive Guide, 2015, India ranks 3rd in egg production whereas 4th in chicken meat production in the world (APEDA, 2016). Backyard production contributes about 15 percent of total poultry output in India (Landes et al., 2004).

In the villages, backyard poultry production system is generally based on traditional native breeds, producing both eggs and meat. The potential of indigenous birds in terms of egg production is quite low. These birds hardly lay 80 to $100 \mathrm{eggs} / \mathrm{bird} /$ year.

By rearing of improved breeds of chicken, we can increase the production potential of our birds under backyard, both in terms of eggs/bird/annum and body weight gain per day (Pathak and Nath, 2013). In the recent past, improved backyard varieties (like Vanaraja, Gramapriya, Srinidhi, Giriraja, Chabro, IBL80, etc.) were developed mostly by public sector organizations and a few (like Kroiler, Rainbow rooster) developed by private organizations are substantially contributing to the total egg and chicken meat production of the country.

Backyard production system can make a useful contribution to dietary protein intake and incomes of weaker section of society (Acamovic et al., 2005).Backyard poultry or family poultry can be used as a powerful tool for generation of employment for women in rural areas, which ultimately leads to generate income and alleviation of their socio- economic status. It is a source of quality nutrition as poultry meat and eggs which reduce the malnutrition in rural poor families (Sharma and Chatterjee, 2009; Rajkumar et al., 2010).

A study was conducted on management aspects in small poultry farms for Maharashtra and Gujarat regions, and concluded that poultry farming may be advocated as a subsidiary occupation to supplement incomes of the rural poor families (Mathur and Gupta, 1979). An income generated from backyard poultry production can be used for food, school fees and unexpected expenses such as medicines etc. (Ramm et al., 1984).

\section{Potentials of backyard poultry farming}

There is no special infrastructure required for running backyard poultry farm. It can be started in small covered structure surrounded by jalidar/ net wire.

In this poultry farming system, rearing of local poultry breeds is an important and best choice for development of backyard poultry production. It is source of livelihood and employment generation tool for the rural population (Sharma and Chatterjee, 2009; Rajkumar et al., 2010).

Backyard poultry unit can be started with as low as one or two hen and a cock. It is better to start such poultry unit with two hens and a cock (Sonaiya, 1990a).

Backyard poultry farm can be started with small initial investment and gives high economic return.

The birds scavenge their feed requirements from utilization of agricultural byproducts, insects, leftover feed and grains in the street or crop field situated nearby dwellings. Thus, the inputs required for feed are very small.

The consumers have liking for eggs and meat of indigenous poultry compared to those 
realized from farm bred chickens or exotic breeds of chicken (Jha and Chakrabarti, 2017).

The consumers are ready to pay higher prices for local native hen eggs and chicken meat.

There is no requirement of hired labour. It boosts up of family income for better utilization of family members who are not able to perform other tough agricultural works.

In backyard production system, the farmers have option to sale the birds and eggs at any time anywhere with cash, so this poultry farming system is called as poor's men 'ATM'.

The birds are raised in natural environment with less stress, so quality of chicken and egg is better than chicken as well eggs produced at commercial poultry farm.

Bird droppings are a very good source of nutrients like $\mathrm{N}, \mathrm{P}$ and $\mathrm{K}$. Droppings may be used as organic fertilizer to improve soil fertility.

The poultry birds reared in the backyard poultry farming are also important from the biodiversity point of view as they act as a natural scavenger.

Birds kept under Backyard poultry farming are very hardy and requires little veterinary healthcare.

\section{Features of bird for backyard poultry farming}

Selection of breed of chicken for backyard farming solely depends on your needs. Chicken breeds can be divided into three basic categories: birds for meat, eggs and dual purpose.

Backyard poultry farming system profitability can be increased if we adopt an improved indigenous strain of poultry birds (Chatterjee and Rajkumar, 2015) (Table 1).

Improved chicken varieties should have certain features suitable for backyard poultry farming are as follows:

Bird should be hardy in nature and better survivability in adverse conditions. Birds should have adaptability to be reared in village/free range condition.

Good broodiness/mothering ability to care newly hatched chicks.

Bird should be a good scavenger so it can maintain itself under food scarcity.

The birds mostly reared under this system are preferred to lay brown eggs.

Birds should be attractive and have coloured plumage.

Birds should have fighting and escaping ability from predators.

They should have good disease resistance against common poultry diseases.

Other breeds of poultry suited for backyard system and found in different parts of India

\section{Jharsim}

Jharsim is a dual purpose breed of poultry and suitable for tribal area of Jharkhand. The bird performs better on low level of nutrition with faster growth, optimum egg production and better adaptability to agro climatic conditions of Jharkhand.

The breed has proven to be more resistant to diseases and can survive in natural habitat without much care. The birds weigh 1600$1800 \mathrm{gm}$ at maturity under backyard poultry farming system.

These birds lay first egg at 6 months of age. The birds have the capacity to lay $165-170$ eggs under backyard system.

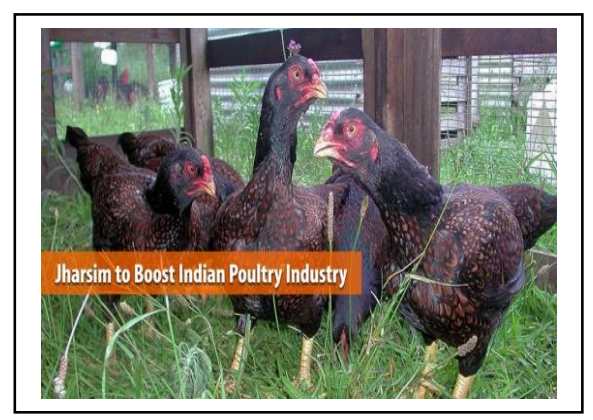




\section{Kamrupa}

It is mainly found in Assam. It is a crossbred, developed by crossing Assam local ecotype (25\%), Coloured Broiler (25\%) and Dalhem Red $(50 \%)$ population. It is reared under backyard system. The average body weight at 20 weeks of age is $1.3-1.5 \mathrm{~kg}$ in female and 1.8-2.2 $\mathrm{kg}$ in male. The annual egg production is 118-130eggs with an egg weight of $52 \mathrm{gm}$.

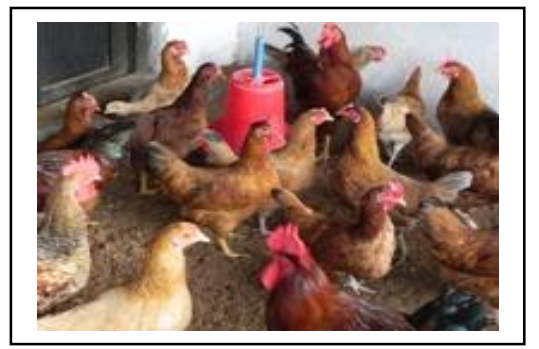

\section{Pratapdhan}

Rajasthan, Birds have longer shank length which helps in self-protection from predators in backyard areas and has capacity to survive on low plane of nutrition (low and negligible input) and harsh climatic conditions. It lays brown eggs and egg weight is around $50 \mathrm{gm}$. It has fast growth rate with an average adult body weight at 20 weeks of age ranged from 1478 to $3020 \mathrm{~g}$ in males and 1283 to $2736 \mathrm{~g}$ in females. The age at sexual maturity was 170 days. Annual egg production is 161 .

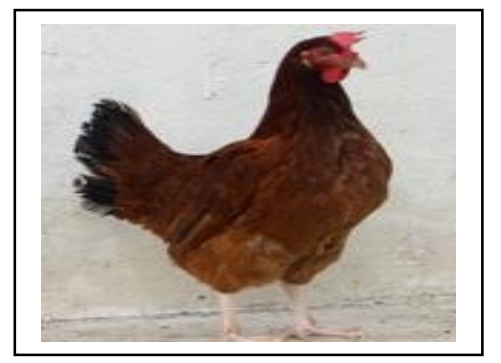

\section{Narmadanidhi}

It was developed at AICRP centre Jabalpur has $25 \%$ inheritance of native i.e. local breed Kadaknath and $75 \%$ of improved broiler germplasm (Jabalpur col.). It is dual purpose Adult body weight ranged from 1.5 to $2.2 \mathrm{~kg}$ in males and 1.3 to $1.7 \mathrm{~kg}$ in females. The annual egg production is 181 eggs in backyard system having brown shell egg weighing up to $50 \mathrm{gm}$.

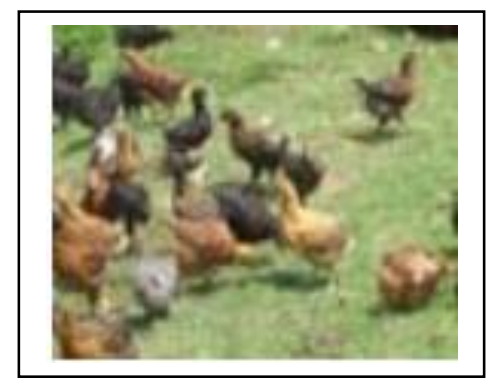

\section{Housing management for backyard poultry farming}

Simple housing is required for backyard poultry farming but, it should be needed for the comfort, protection from sun, rain, predators and efficient production of eggs and meat. Thus proper housing is one of the prerequisites of sound poultry farming and a good housing is comfortable, safe, economical and convenient. If free range system is practiced the birds are let loose in day time for foraging and at night sheltered in shed. Generally 5-10 birds are raised in backyard system for home consumption, 1030 birds for income generation and home consumption but more than 50 birds for primarily income generation purposes (Sonaiya, 1990a). For better production performances certain criteria are as follows:

The poultry house should be in east-west orientation to protect from summer wind and cold stress and also for direct sunlight in winter months.

During summer direct sun light should be avoided to reduce the summer stress in 
birds.

Low cost housing material like wood, bamboo, grass, thatch etc can be utilized.

The poultry house should be free from water seepage or moisture.

Floor should be in elevated land or above ground level (minimum 2ft) and free from water crack, easily cleaned, rat proof and durable.

There should be free air movement in upper part of the shed to reduce gas formation inside the shed.

Height of the side wall in poultry house is generally $7 \mathrm{ft}$ to $8 \mathrm{ft}$. The centre height is $9 \mathrm{ft}$ to $12 \mathrm{ft}$ with slope in either side.

Roofing material like thatch, tiles, asbestos etc can be used.

Brooder house should have easy ventilation and wire netting which is used for open air ventilation.

Provision of bulb fitted above the ground as hover may be utilized to keep the chicks warm.

\section{Brooding of chicks}

Brooding means to care day old chick upto growing period. In backyard poultry farming, there are two types of brooding of chicks followed viz. natural brooding and artificial brooding.

\section{Natural brooding}

Indigenous breeds of chicken are having good broodiness properties and hens are very good sitters. A broody hen can sit on 12-15 fertile eggs for incubation. The hen is provided nest with bedding or litter materials. A broody hen can easily take care for brooding of 10 to 12newly hatched chicks. After hatching the chicks are let loose along with mother for scavenging. During night mother along with young chicks should be kept separately from other birds inside the shed.

\section{Artificial brooding}

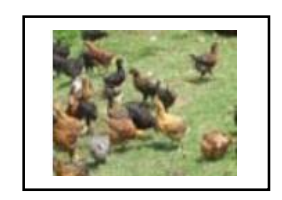

In artificial brooding of chicks, artificial heat is necessary. Artificial heat can be provided by different heat sources like electricity, gas, kerosene, wood, sawdust etc. Wood, charcoal or sawdust is used as fuel in Bhukari and it is an ideal source of artificial heat when there is shortage of electricity, gas and kerosene. The chicks should be protected from direct contact with artificial heat source, a chick guard made up of card board or metallic guard can be used in brooder house. The height of chick guard is 15 to 18 inches and is placed in circular shape at a distance of 3 feet away from the hover. The optimum temperature is $95^{\circ} \mathrm{F}$ in first week and it can be reduced by $5^{0} \mathrm{~F}$ per week up to 6 week till $70^{\circ} \mathrm{F}$. Light in brooder house is necessary to increase feed consumption for maximum growth in a short period and also to prevent stampeding or piling. There should be provision of continuous light of 24 hours in brooder house up to 6 weeks. Light is required 15-16 hours which induces sexual maturity and egg production during laying period (Leeson et al., 2005).

\section{Feeding management}

In backyard poultry farming the feed cost input is considered to be minimum or nil. In this poultry farming system, the birds are let loose for scavenging in the open areas during day time. They feed on insects, termites, seeds of grasses and weeds, leftover grains, crop residues and household wastes for their protein, energy, minerals and vitamins requirement. Feed for birds can be prepared by ingredients like broken rice, rice bran, wheat bran, wheat, bajra and grains as well wastage of pulses etc. In backyard poultry 
farming generally feeding is practiced two times in a day (morning and evening) if birds are in confined area. An adult bird can require feed 105 to 120 gram/day. The bird may be supplied with extra feed ration@ @ 30 to 40 $\mathrm{gm} / \mathrm{bird} /$ day for better performance when they are reared on scavenging (Sonaiya, 2004). The balanced ration may be formulated with appropriate percentage of maize, bajra, rice bran, rice polish, wheat bran, oil cake, fish meal, shell grit or lime stone along with salt, minerals and vitamins. Local available ingredients should be considered first during feed formulation which may reduce the feed cost. The poultry feed should contain at least 17- $20 \%$ protein with energy level (ME) more than $2600 \mathrm{kcal} / \mathrm{kg}$ feed.

\section{Health care management}

For better health care in backyard poultry farming birds should be vaccinated against viral diseases. The diseases that mostly affect the birds are Ranikhet disease, Marek's Disease, Gumbro disease etc. Vaccination schedule should be followed in backyard poultry production system where the disease prevalence to protect birds from the diseases at farm and it should be done timely and regularly. Vaccination schedule for poultry birds is given in Table 3 .

Deworming of birds for parasites should be done at 3-4 months interval to maintain a healthy and worm free flock. Other bacterial, protozoal and mycoplasma diseases that affect the poultry birds are CRD, Coccidiosis, infectious coryza and Salmonellosis etc. At proper time interval there should be provision of spray disinfectants for bio-security and to protect the flock in backyard system from diseases. Vaccination against Ranikhet
Disease should be repeated at an interval of every 60-90 days during laying period (Ratanasethakul, 1988).

Improved desior backyard types of poultry birds can be resourced from the following organizations

1. Breeds from Central Aviation Research Institute (CARI), Bareilly (UP) (Table 2)

2. Directorate of Poultry Research (ICAR), Hyderabad

3. Central Poultry Development Organiztion (CPDO), Chandigarh

4. Guru AngadDev Veterinary and Animal Sciences University, Ludhiana (Punjab)

5. Karnataka Veterinary, Animal, and Fishery Sciences University, Bangalore

Utilization of poultry manure as in vermicompost preparation

Vermicompost is a bio-fertilizer produced by earthworm feeding on organic waste material of animals, poultry and plant residues. Poultry manure is good source of organic materials which are required by earthworm for making vermicompost. Poultry manure is having about 30 percent protein. This bio-compost or vermicompost is an odorless, clean, organic material containing adequate quantities of $\mathrm{N}$, $\mathrm{P}, \mathrm{K}$ and several micronutrients essential for plant growth. It enriches soil fertility and improving its physicochemical and biological properties (Audu et al., 2015). It is a recycled biological product. It is a major component of organic farming system. The level of nutrients in compost depends upon the source of the raw material and the species of earthworm. 
Table.1 Indigenous chicken breeds of India for backyard poultry

\begin{tabular}{|c|c|}
\hline Breed Characters & Varieties/ Locations \\
\hline $\begin{array}{l}\text { 1.Aseel is ancient chicken breed of India. It is known for its high stamina, majestic gait and } \\
\text { fighting abilities.The popular varieties of Aseel are, Peela (Golden red), Nuri (White), Kagar } \\
\text { (Black), Chitta (Black and white spotted), Java (Black), Sabja (White and golden or black } \\
\text { with yellow or silver), Teekar (brown) and Reza (light red). Pea comb, bright red wattle and } \\
\text { ear lobes and long neck. The eyes are compact, well set and having bold looks. The legs are } \\
\text { strong and straight. Standard body weight of cocks ranges from } 4 \text { to } 5 \mathrm{~kg} \text { and hens } 3 \text { to } 4 \mathrm{~kg} \text {. } \\
\text { On an average the Aseelattain age of sexual maturity at } 196 \text { days. Annual egg production: } \\
\text { 92. Average egg weight: } 50 \text { gm. }\end{array}$ & $\begin{array}{l}\text { Andhra Pradesh, } \\
\text { Chhattisgarh, Orissa }\end{array}$ \\
\hline $\begin{array}{l}\text { 2.Busra birds are found in the border regions of Maharashtra and Gujarat. It is medium in } \\
\text { size and deep body. It is alert in nature. Plumage is mostly white mixed with black feathers. } \\
\text { Comb is red, single, medium in size and erect. Beak is yellow and wattles are red, with a } \\
\text { yellow shank. Standard body weight of Cocks } 0.85 \text { to } 1.25 \mathrm{Kg} \text { and Hens: } 0.8 \text { to } 1.2 \mathrm{Kg} \text {. } \\
\text { Average agesof maturity at } 150-200 \text { days. Annual egg production: } 40-55 \text { with hatchability of } \\
\text { eggs: } 60-85 \% \text {. Average egg weight } 28-38 \mathrm{gm} \text {. The shell colour is primarily light brown. } \\
\text { The birds are suited for backyard poultry or free range system. The bird is preferred as a } \\
\text { meat bird. }\end{array}$ & $\begin{array}{c}\text { Gujarat and } \\
\text { Maharashtra }\end{array}$ \\
\hline $\begin{array}{l}\text { 3.Chittagong is also known as Malay. The birds found in the North Eastern states of } \\
\text { India.Average body weight of Cock ranges from } 3.5-4.5 \mathrm{~kg} \text { and Hen ranges } 3-4 \mathrm{~kg} \text {.It is } \\
\text { estimated to lay } 70-120 \text { eggs per annum.These birds are reared for dual purposes. The } \\
\text { popular varieties are buff, white, black, dark brown and grey.The bird is very strong, hardy } \\
\text { in nature with aggressive temperament. It is also a good game bird.It is considered as the } \\
\text { tallest breed. It is well muscled, has prominent eyebrows, has a featherless shank and } \\
\text { upright stance. }\end{array}$ & Meghalaya and Tripura \\
\hline $\begin{array}{l}\text { 4.Kadaknath is most popular name but it is originally known as Kalamasi. The breed is } \\
\text { Kalamasi, meaning a fowl with black flesh. The native home tract of this breed is Jhabua } \\
\text { district of Madhya Pradesh. The skin, beak, shanks, toes and soles of feet are slate like in } \\
\text { colour. The comb, wattles and tongue are purple. The black colour of muscles and tissues is } \\
\text { due to deposition of melanin pigment, which causes increase in protein and decrease of fat } \\
\text { and muscle fiber. Average body weight of cock: } 1.5 \mathrm{~kg} \text { and Hens: } 1.0 \mathrm{~kg} \text {. A hen lays about } \\
80 \text { eggs per year and average egg weight } 46.8 \mathrm{gm} \text {. The eggs are light brown in colour. The } \\
\text { bird is resistant to diseases. }\end{array}$ & Madhya Pradesh \\
\hline
\end{tabular}


5.Punjab brown is mainly found in rural areas of Punjab and Haryana. Plumage colour is mostly brown and the pattern is usually solid but is sometimes spotted or striped. The comb is red, of single type and erect in position. Average body weight of cock is ranges from 2-3 $\mathrm{kg}$ and hen is $1.5 \mathrm{~kg}$. These birds lay first egg at the age: $5-6$ months and egg production $60-80$ eggs per annum. Egg shell colour is mostly light brown. It is dual purpose breed, yielding good quality meat and eggs. Birds are reared in the backyard system and shelter is the form of small enclosures mostly made up of mud and sometimes of wood with thatch on top.

6.Mewari chicken is found in Central and Southern part of Rajasthan. It is dual purpose breed for egg and meat under backyard system on scavenging feeding. Adult body weight of cock is about $1.9 \mathrm{~kg}$ and hen is about $1.2 \mathrm{~kg}$. Annual egg production ranges from 37 to 52 . Average egg weight is $53 \mathrm{~g}$. Among the indigenous varieties, scientists claim that these are well adapted to the local climatic conditions and its survivability is better in adverse environmental conditions. Its meat and eggs fetch better prices compared to other intensive commercial farm chicken breeds. This breed may attack on its predators like dogs, cats and other predator birds.

7.Average body weight of cocks: $1.7-1.8 \mathrm{~kg}$ and hens: $1.4-1.5 \mathrm{~kg}$. Average annual egg production: 25 - 35. Annual egg production: $80-85$. These birds are mainly reared by tribal communities in South Gujarat for backyard poultry farming.

8.Average body weight of cocks: $3.12 \mathrm{~kg}$ and hens: $2.22 \mathrm{~kg}$. Average annual egg production: 25 - 35. The Danki is basically used as a fighter bird like Aseel.

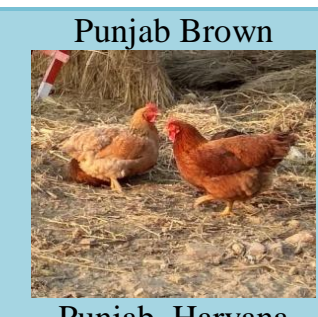

Punjab, Haryana

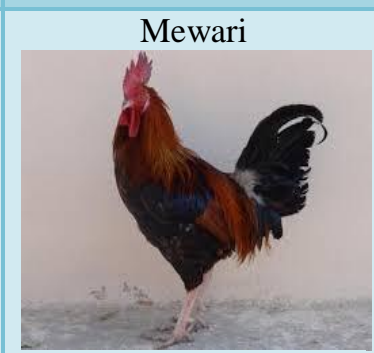

Central and Southern part of Rajasthan

Ankaleshwar

Gujarat

Danki

Andhra Pradesh (AP)

9.Average body weight of cock: $1.79 \mathrm{~kg}$ and Hen: $1.63 \mathrm{~kg}$. Annual egg production: $60-70$. These birds are reared under backyard or free-range systems.

10.Average adult body weight: Cock: $2.16 \mathrm{~kg}$ and Hens: $1.43 \mathrm{~kg}$. Annual egg production: $45-60$. It is a breed reared mainly by the nomadic people.

11.Jet black in colour with red comb and wattles while the shanks are white in colour. Average weight: Cock: $1.5 \mathrm{~kg}$ and Hen: $1.2 \mathrm{~kg}$. Annual average egg production: 130.

12.Average adult weight: Cock is $2.48 \mathrm{~kg}$ and $\mathrm{Hen}$ is $1.85 \mathrm{~kg}$. Annual egg production: $30-$ 40.Average egg weight: $42-43 \mathrm{gm}$. The birds are reared in the backyard farming system primarily for meat.

13.The indigenous chicken of Kashmir thrives at an altitude of 1,500 to 2,000 meters above sea level. Average body weight ofcock: $1.72 \mathrm{~kg}$ and hen: $1.25 \mathrm{~kg}$. Average egg weight: $46.06 \mathrm{gm}$. This breed is most suitable for cold climates and mountainous.

14.The body weight at 10 monthsranges from 1.0 to $1.3 \mathrm{~kg}$. Annual egg production: $60-$ 70.This bird is reared by the Mishing or Miri Tribes of Assam.

15.The bird is well adapted to the tropical environment of the Nicobar Islands and is a good layer among native breeds.

16.Average body weight of an adult male $1.62 \mathrm{~kg}$ and a female $1.24 \mathrm{~kg}$. Eggs are tinted. Annual egg production: 60 - 80.Average egg weight: $40-41 \mathrm{gm}$.
Daothigir

Assam

Ghagus

Karnataka and AP

HarringhataBlackWest Bengal

Kalasthi

Andhra Pradesh (AP)

Kashmir Favorolla

Kashmir

Miri

Assam

Nicobari

Nicobar islands

Tellichery

Kerala

(Source: www.nbagr.res.in/regchi.html) 
Table.2 Desi Types/Backyard Types Improved Breed developed by Central Avian Research Institute (CARI), Izatnagar, Bareilly (UP)

1. CARI NIRBHEEK (Aseel Cross): Average body weight at age of 20 weeks, cock: $1847 \mathrm{gm}$ and hen: $1350 \mathrm{gm}$. Annual egg production: 198. It adapted to all regions in India and fighting in nature.

2. CARI SHYAMA (Kadakanath Cross): Average body weight at age of 20 weeks, cock: 1460gm and hen: 1120gm. Annual egg production: 210. These birds sexually matured at age of 170 days. Muscles and internal organs are black.

3. HITCARI (Naked Neck Cross): Average body weight at age of 20 weeks, cock: $1756 \mathrm{gm}$ and hen: $1320 \mathrm{gm}$. Annual egg production: 200 . It suitable to hot humid coastal region and its naked neck decreases heat stress.

4. UPCARI (Frizzle Cross): a)Kadakanath x Dehlam Red, b)Aseel x Dehlam Red, c)Naked Neck x Dehlam Red and d)Frizzle x DehlamRed:These birds are best suited for backyard system of poultry production and disease resistance.
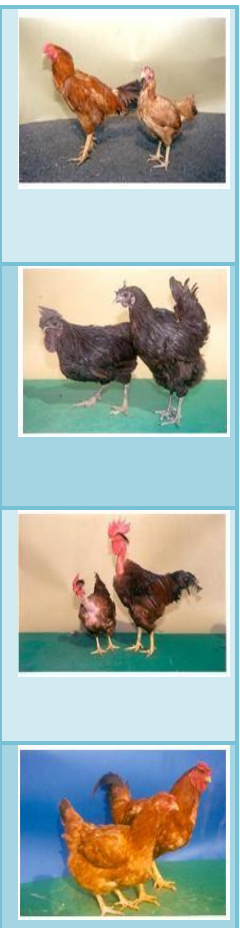

The improved verities of birds can be recommended for backyard poultry system, developed by central and state institutions in India

Gramapriya is a breed of chicken developed by the Project Directorate on Poultry, Hyderabad. This has been developed for backyard rearing system. The bird starts laying eggs at an age of 175 days. These birds can lay eggs above 200in 72 weeks of life cycle.

Vanaraja is developed by the Project Directorate on Poultry, Hyderabad. It is the best suitable for rural communities where it can be raised in backyard system on natural, scavenged food with minimal supplementation. They lay up to 110 eggs per year and weigh 1.0 to $1.2 \mathrm{~kg}$ (2.2 to $2.6 \mathrm{lb})$ at age $180-200$ days.

Giriraja is a breed of chicken developed by Karnataka Veterinary, Animal, and Fishery Sciences University in Bangalore. They lay annually 130-150 eggs with brown in colour and each egg weighing 52-55 gm. Body weight is ranges between 2.5 to $3.5 \mathrm{~kg}$ at maturity age.

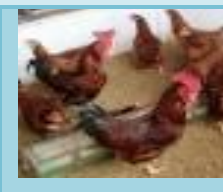

(Source:www.icar.org.in/cari/native.html and www.vikaspedia.in/agriculture/poultry) 
Table.3 Vaccination schedule for poultry birds

\begin{tabular}{|c|l|l|l|c|c|}
\hline $\begin{array}{c}\text { Sl. } \\
\text { No. }\end{array}$ & $\begin{array}{c}\text { Age of birds } \\
\text { (days) }\end{array}$ & $\begin{array}{c}\text { Name of } \\
\text { Disease }\end{array}$ & Name of Vaccine & Doses & $\begin{array}{c}\text { Route of } \\
\text { Vaccination }\end{array}$ \\
\hline 1. & Day one & Marek's Disease & HVT MD Vaccine & $0.2 \mathrm{ml}$ & S/C \\
\hline $\mathbf{2 .}$ & $\mathbf{5}$ & Ranikhet Disease & Lasota & One drop & Eye or nostril \\
\hline $\mathbf{3 .}$ & 12 & Gumboro disease & Intermediate plus & One drop & Eye or nostril \\
\hline $\mathbf{4 .}$ & 24 (Booster) & Gumboro disease & Intermediate plus & -- & Drinking water \\
\hline 5. & 28 (Booster) & Ranikhet Disease & Lasota & -- & Drinking water \\
\hline
\end{tabular}

A fine worm cast is rich in $\mathrm{N} \mathrm{P} \mathrm{K}$ besides other nutrients. Nutrients in vermicompost are in readily available form and are released within a month of application.

\section{Vermicomposting for rural development}

Large quantity of potential agro-industrial wastes and byproducts are thrown out as wastes/under-utilized by the local population since they are not aware of its importance. The materials can be utilized profitably by vermicomposting, which is a low cost technology. Unemployed rural population can do this, as part time/ full time profession if they are aware of the technical knowhow to utilize the materials. Awareness about Vermiculture and vermicomposting will motivate the rural people to start Vermicompost units, which can fetch regular income.

\section{Revenue generation through vermiculture and vermicomposting}

Vermi-technology is popular because it is a simple methodology with low investment and does not need sophisticated infrastructure. To process $10-15 \mathrm{~kg}$ of organic matter daily, it would require about 1.5 sq. meter of space with family member. Innovative, interested and talented rural people can be successful entrepreneurs in vermicompost production and to get job opportunities with the help of self-employment schemes.
Backyard poultry production system is the most popular poultry farming practice in weaker section of society in rural areas. It plays an important role as secondary source of income. Knowingly or unknowingly, these people preserve the germplasm of the native breeds in their natural habitat.

Upgradation of the native breed of chickens helps to increase the productivity of the bird and also their conservation in their natural habitat. There is no special requirement for backyard poultry farming. In the villages, backyard poultry production system is generally based on traditional native breeds which produce both egg and meat. By rearing of improved breeds of chicken, it can increase egg and meat production creates more income.

It provides quality nutrition as poultry meat and egg which reduce the malnutrition among rural population of country. The overall aims of development of backyard poultry system are to reduce poverty, malnutrition and increase income of rural poor families. It helps in conserving the natural resources and maintaining biodiversity. It also helps to promote respect in society.

\section{References}

Acamovic, T., Sinurat, A., Natarajan, A., Anitha, K., and Chandrasekaran, D. et al., 2005. Poultry. In E. Owen, A. Kitalyi, N. Jayasuriya and T. Smith, eds. Livestock and wealth creation: improving the 
husbandry of animals kept by resourcepoor people in developing countries. Nottingham, UK, Nottingham University Press. Pp. 301-332.

APEDA, Poultry Production in India - The Current Scenario, March 10, 2016.

Audu, M., Haliru, M., and Isah, A. M. 2015. Influence of Poultry Droppings on Soil Chemical Properties and Performance of Rice (Oriza sativa L.) in Sokoto, Sudan Savanna Zone of Nigeria International Journal of Plant and Soil Science. 7(2): 128-135.; Article no. IJPSS.2015.138.

Backyard poultry production is an age old practice in rural India. Most of the backyard poultry

Chatterjee, R.N., and Rajkumar, U. 2015. An overview of poultry production in India. Indian Journal of Animal Health. 54(2): 89-108.

Jha, B. K., and Chakrabarti, A. 2017. Back yard poultry farming as a source of livelihood in tribal village: an economic appraisal. International Journal of Agricultural Science and Research. 7: 267-272.

Landes, M., Persaud, S., and Dyck., J.2004. India's poultry sector: development and prospects. Economics Research Service: Agricultural and Trade Report WRS-0403. Washington DC, United States Department of Agriculture.

Leeson, S., Caston, L., Lewis, P.D.2005. Rearing and laying performance following various step-down lighting regimens in the rearing period. Poultry Science. 84: 626-632.

Mathur, D. P., and Gupta, V. K.1979. Management in Small Poultry Farms. New Delhi: Abhinav Publications.
Pathak, P. K., and Nath, G. B. 2013. Rural Poultry Farming with Improved Breed of Backyard Chicken. World's Poultry Research. 3(1): 24-27.

Rajkumar, U., Rama Rao, S.V., and Sharma, R. P. 2010. Backyard poultry farmingchanging the face of rural and tribal livelihoods. Indian Farming. 59: 20-24.

Ramm, G., Balzer, G., Eckert, M. V., Hugo, R., Massler, B., Müller, R., and Richter, J. 1984. Animal Husbandry in East Kalimantan: integration of animal husbandry into transmigrant farming systems in the middle Mahakam area in East Kalimantan, Indonesia. Fachbereich Internationale Agraentwicklung, Technische Universität Berlin, Berlin, Publication No. 84: 4- 5.

Ratanasethakul, C. 1988. Study of Newcastle disease vaccination one to four times a year in native chickens raised in the village. Thai Journal of Vet. Medicine. 18(1): 3-7.

Sharma, R. P., and Chatterjee, R.N. 2009. Backyard poultry farming and rural food security. Indian Farming. 59: 36-37.

Sonaiya, E.B. 2004. Direct assessment of nutrient resources in free-range and scavenging systems. World's Poultry Science Journal. 60: 523-535.

Sonaiya, E.B. 1990a. The context and prospects for development of smallholder rural poultry production in Africa. Proceedings International Seminar on Smallholder Rural Poultry Production, 9-13 October, 1990, Thessaloniki, Greece. 1: 35-52.

WATT Executive Guide to World Poultry Trends. $2015 \quad$ from www.poultrytrends.com

\section{How to cite this article:}

Shashi Pal, Bhanu Prakash, Anil Kumar and Yashwant Singh. 2020. Review on Backyard Poultry Farming: Resource Utilization for Better Livelihood of the Rural Population. Int.J.Curr.Microbiol.App.Sci. 9(05): 2361-2371. doi: https://doi.org/10.20546/ijcmas.2020.905.269 